\section{UNUSUAL INCUBATION BEHAVIOUR OF THE RUFFED GROUSE}

\section{By Wm. Anaka, Spirit Lake}

The spring of 1959 was exceptionally dry, resulting in extensive burning of dry marsh growtr throughout the meadow area of the Spirit Lake district. One such fire on May 16 escaped into adjoining woods and burned over approximately 50 acres before being brought under control. All ground cover-leaves, brush and dead wood-was completely destroyed. While walking through the area next day I located a Ruffed Grouse nest, the sitting female readily visible owing to lack of protective cover. All surrounding ground cover, including part of the nest rim and the feather lining had been burned. The nest contained 11 eggs, two of these cracked by the heat. One cracked egg was examined and the contents were found to be thoroughly baked.

Throughout the summer the nest was visited on an average about three times a week. During the last few weeks of incubation visits were more frequent, as often as four times a day. During all these visits, totalling about sixty, the female was always on the nest except on one or two occasions. First indication of loss of incubating instinct was noted on August 5, and incubation ceased on August 7. In a total of ten visits during the last three days, the female was found on the nest only five times. On August 8 the eggs were abandoned and cold. Next day tree nest was raided by a predator. Altogether incubation continued for at least twelve weeks, several times the normal incubation period for this species (24 days).

\section{BIRDS IN AN APPLE TREE}

By L. G. Saunders, Saskatoon

Rescue apple-crabs were so plentiful this year that our tree was not picked clean, and, standing outside the dining room window it forms an excellent bird-watching station. Throughout September and the first half of October a constant succession of birds visited it for the mealy, softened fruit. First of these were the Robins, as many as a dozen in the tree at once. With them, at different times, were Cedar Waxwings, Write- throated Sparrows, a Flicker, a Hairy Woodpecker, a Purple Finch, Juncos and an Olive-backed Thrush. I am not sure of the apple-eating habits of the last two, but all the rest were definitely eating the flesh, or perhaps the seed of the fruit. Of course, inquisitive House Sparrows came to see what they were missing, but did not stay to feed.

But the greatest prize was a male House Finch (or Linnet) which paid a brief call about October 15th. I was completely stumped by this stranger at the time and could find nothing like it in Taverner, but Salt and Wilk mention it as a rare visitor in Alberta. The red cap and eyestreak, red rump and rosy breast were very evident, and the fruit-eating habit is very characteristic; I did not know enough to look for the streaky flanks which Peterson gives as the best field mark. Since it was quite obviously not a Purple Finch nor a Redpoll there seems to be no chance of a mistake in identification. Possibly others along the migration route will have seen one of these rarities.

\section{DECREASE IN DUCKS AT CUMBERLAND HOUSE}

\section{By Russell Robertson, Cumberland} House

The ducks are decreasing in numbers every year at Cumberland House. The Pintail, Canvasback, Blue-winged Teal and Shoveler are very scarce this year. Even the Mallard and Scaup, our stand-bys, have shown a marked decrease.-October 8, 1959.

\section{CHRISTMAS BIRD COUNT 1959}

In your report, list the numbers of each species seen on the ONE BEST DAY between December 23 and January 3; in addition, list other species (number of individuals and date seen) between Dec. 23Jan. 3.

SEND REPORTS AS SOON AS POSSIBLE TO

Dr. Stuart Houston, Box 278, Yorkton, Sask. 